\title{
Language of Communication as an Important Condition for the Development of National Identity During Ukrainian Students
}

\section{Мова спілкування як умова розвитку національної ідентичності студентської молоді}

\author{
Lyubov Spivak ${ }^{1}$ \\ Dr. in Psychology, \\ Professor
}

\author{
Любов Співак ${ }^{1}$ \\ доктор психологічних наук, \\ професор
}

E-mail: lubov spivak@ukr.net

orcid.org/0000-0002-3653-5432

\section{Olena Kovalenko ${ }^{2}$}

Dr. in Psychology,

Associate Professor

\section{Олена Коваленко}

доктор психологічних наук, доцент

\footnotetext{
E-mail: olenagk@ukr.net

orcid.org/0000-0001-5395-2329
}

\author{
${ }^{1}$ National Pedagogical \\ Dragomanov University, \\ Department of Theoretical and \\ Counselling Psychology \\ $\triangle$ 9, Pyrogova Str., Kyiv, \\ Ukraine, 01601 \\ ${ }^{2}$ Poltava V.G. Korolenko National \\ Pedagogical University, \\ Department of Psychology \\ $\triangle 2$, Ostrogradski Str., Poltava, \\ Ukraine, 36000
}

${ }^{1}$ Наиіональний педагогічний університет імені М.П. Драгоманова, кафедра теоретичної та консультативної психології $凶$ вул. Пирогова, 9, м. Київ, Україна, 01601

\footnotetext{
${ }^{2}$ Полтавський національний педагогічний університет імені В.Г. Короленка, кафедра психології $\triangle$ вул. Остроградського, 2, м. Полтава, Україна, 36000
} 


\section{ABSTRACT}

The article is dedicated to such an important condition for the development of the national identity of Ukraine higher educational institution students as the language of their communication. The author's understanding of the psychological nature of the phenomenon of "national identity" is presented which consists of understanding and evaluating by the personality one's own nationality. Personality's national identity is the result of the awareness of its own affiliation with a certain nation and its emotional evaluation of this membership. The students' age is sensitive to the development of personality national identity. The main psychological positions of scientists about the conditions of development of national identity, in particular the language of communication, are presented. O. Potebni and D. Ovsyaniko-Kulikovsky works dedicated to the importance of the language of communication in the development of the national identity of Ukrainians are presented. The language of communication of Ukrainian students with significant others (relatives, friends, peers) is empirically determined and their types of national identity are determined. It is proved that the main condition for the development of positive national identity of Ukraine higher educational institution students is their communication with other significant others by means of the national language. It is revealed that most students with a positive national identity speak just Ukrainian with their significant others, or they speak several languages - more often Ukrainian and rarely in Russian and English. The prospects for further research are seen in the study of the influence of other nation features on the development of the Ukrainian student's national identity and the influence of cross cultural features of the language of communication on the student's national identity development.

Key words: national identity, personality, development, language of communication, students.

\section{Introduction}

In the conditions of the significant modern world globalization and the integration of the Ukrainian state into the world's sociocultural space, the problem of the development of the national identity of its citizens is actualized. The State Concept of National-Patriotic Education of Children and Youth emphasizes the importance of developing national identity, national consciousness and national selfconsciousness among students, as well as the importance of raising their respect for the language, culture and traditions of the nation and the need to preserve its values. In view of the urgent state projections, the importance of research on the main conditions for the development 
of positive national identity among university students is increasing in Ukrainian psychological science. After all, the students' age is sensitive to the development of personality national self-consciousness and national identity.

An analysis of modern scientific psychological research on the issues of the development of national identity among university students has made it possible to establish that scholars weren't deeply interested in its aspects.

O. Lozova's scientific work presented to the result of the psychosemantic research of the ethnic and sociocultural determinism of the university students' perceptions of journalistic texts. The scientist empirically established the insufficient of ethnic competence and demanding of students' aged 18-25 years perceptions of journalistic texts, in comparison with older respondents aged 26-38 years (Lozova, 2009).

O. Shevchenko's subject of the study was the role of national identification in the formation of the «I-image» of a personality who is 14-20 years old. The psychologist empirically identified regional differences in the investigated process. She found that respondents from Western Ukraine had the highest level of identification with their nation, compared to their peers from the southern and north-eastern regions of Ukraine. According to her position, these differences are due to worldview and characterological differences of respondents from different regions. It has been established that their majority is distinguished by an indifferent, minority - positive or negative national identity, which testified to the content of the «I-image», autostereotypes and heterosterotics. It is proved that positive national identity is correlated: the positive «I-image», the need for young people belonging to the nation, the high degree of identification with it, the orientation towards the values of the nation, indifference to its features (Shevchenko, 2005).

The research of D. Piontkovsky is dedicated to psychological peculiarities of development of the students' national identity. The scientist empirically established the uneven intensity of the development of cognitive and affective components of national identity among Ukrainian university students studying in different specialties, due to their specificity. Namely - at the stage of vocational training, these components of national identity are most actively developed by future 
teachers of Ukrainian history and Ukrainian language and literature. During the course of their studies, they systematically study many of the disciplines that contribute to the intensive development of the national identity (Ukrainian history, archeology of Ukraine, Ukrainian ethnology, ethnopsychology, history of Ukrainian culture, oral folk art, history of the Ukrainian language, Ukrainian literature, religious studies etc). Somewhat less intensity of the development of cognitive and affective components of national identity was found among students - future specialists in the fields of law, culture, journalism, philosophy, psychology, speech therapy and social pedagogy. After all, during vocational training, they study a few educational disciplines that intensify the development of the national identity (Ukrainian history, Ukrainian language by professional orientation, history of Ukrainian culture, culture and speech technology, ethnic psychology, religious studies etc). The smallest intensity of the development of these components was recorded among the students future specialists in the fields of geodesy, mathematics, medical practice, transport technology (road transport). This is due to the fact that in the beginning of vocational training they study just few of the educational disciplines that influence the intensity of the development of national identity - the history of Ukrainian culture, the history of Ukraine, the Ukrainian language according to professional orientation (Piontkovska, 2017).

The conducted theoretical analysis showed that beyond the scientific interest of foreign and local psychologists have not solved the issue about the language of communication as an important condition for the development of the national identity of Ukrainian students. The answer to this question required its theoretical and empirical study. In particular - the primary definition of the psychological essence of the phenomenon of «national identity» and the establishment of basic conditions for the development of the personality's national identity.

According to our understanding, national identity is one of the main subjective attributes of every person belonging to a particular nation that one considers to be one's own. Other such features are: national consciousness, national self-consciousness and national character. The main manifestations of these traits are: common feelings by the representatives of the nation, their common aspirations to build the state and to continue the history of their nation. Instead, language, like culture and territory, belongs to the objective features of a nation. 
A distinguishing feature of a nation is a state with a specific political self-government and level of economic development. Each of these features can provide both an integrative and a differential function in relation to a nation. However, the degree of significance of these features among representatives of different nations may be unequal (Spivak, 2015).

To determine the conditions for the development of national identity, we consider it important to consider the provisions of M. Barrett on the content of the cognitive and affective components of this phenomenon. According to the position of the scientist, the cognitive component of this phenomenon is presented: people knowledge about the existence of a nation, its territory, symbolism, history, customs and traditions; the belief in the community of the origin and affinity of the representatives of a particular nation; confidence in the existence of typical features of a particular nation; enrolling yourself in a separate nation; attributing to the representatives of a certain nation the generality of origin, general affinity and typical qualities, and the belief in its interrelation. The affective component of national identity is presented in the degree of people commitment to this identity (significance of national membership, national pride, national self-esteem etc) and its subjective relevance (Barrett, 1996).

No less important for establishing the basic conditions for the development of one's national identity is an overview of the regulations made by P. Gnatenko and V. Pavlenko. Scientists studied the phenomenon of «national identity» from the philosophical and psychological point of view.

They supported the position of E. Smith on the existence of identity at the level of personality and collective and on the multidimensionality of the phenomenon «national identity». The national identity constructs the following results of identification of the personality associated with the features of the nation, according to E. Smith, namely - historical territory, common myths and historical memory, language, common mass and public culture, a common economy, the only legal rights and obligations for all its representatives (Smith, 1996).

According to P. Gnatenko and V. Pavlenko's position, the development of the personality's national identity is due to the routine level of consciousness, while awareness of identity - the theoretical level of social consciousness. The main factors and conditions for the 
development of the personality's national identity are the national idea, self-consciousness, feeling, culture, language, spirituality and economic independence of the nation (Gnatenko \& Pavlenko, 1999).

C. Suleiman and D.C. O'Connell investigated the role of ethnic and gender identity in the public speaking of current American politicians. Researchers have established connection between ethnicity and gender for the well-known politicians (Suleiman \& O'Connell, 2008).

C. Altman, R. Dekeyser, I. Alfi-Shabtay and D. Ravid considered the issue of migrant's bilingualism within the psycholinguistic. Age peculiarities of migrants' assimilation of the second language were the subject of cross-linguistic research by R. Dekeyser, I. Alfi-Shabtay and D. Ravid. Researchers found high verbal abilities in an age group of migrants aged 18-40 (Dekeyser, Alfi-Shabtay \& Ravid, 2010).

K. Altman studied the peculiarities of migrants' communication and indigenous minorities by means of two languages. The scientist has established differences between the possession of two languages for migrants and non-migrants at the level of their crossover memories (Altman, 2015).

The issue of language as a significant condition for the development of national identity was considered by J. Joseph and L. Oakes (2011).

L. Oakes's work presents a historical overview of the relationship between the attitude to language and the strategies of national identity in France and Sweden. The researcher noted the similarity of these two countries due to their membership in the European Union. He stressed the differences in the influence of language on the formation of national identity in these countries. In France, the state model of national identity prevails which assumes the decisive role of the official language. In Sweden, the ethnic language prevails which determines the leading influence on national identity. Special attention deserves the researcher's conclusion about ethnolinguistic consequences of regionalism, immigration, European integration and globalization for the development of the European countries (Oakes, 2001).

The historical overview of scientific opinions on the importance of influence of the official language and the national language on the development of national identity in various countries is revealed in J. Joseph's work. The researcher presented his opinion on the mechanism of the ethnic language construction, on the relationship 
between the ethnic and the official language, on the influence of the ethnic and the official language on national identity in various countries and on the differential cultural context of languages of different nations, etc (Joseph, 2004).

Consequently, considering the considered psychological positions of scientists, we can argue that the language of communication is one of the important conditions for the development of the personality's national identity.

Confirmation of the importance of language as an objective feature of the nation, in the development of the national identity of Ukrainians, which is their subjective feature, we consider the psychological views of Ukrainian linguistic scientist, D. Ovsianiko-Kulikovsky (1922) and O. Potebnja (1993).

According to O. Potebnja, the unity of the language of the representatives of one nation, contributes to its transformation into a nation, the appearance of its own similarity and differences from others, that is, identity. The scientist stressed that the disappearance of the language of the nation predetermined its denationalization; instead, education and culture are leading factors in the development of the national character. However, he stressed that the peculiarities of language and thinking of representatives of different nations sometimes interfere with their mutual understanding. The complication of mutual understanding between them is due to the fact that the peculiarity of the language of representatives of different nations determines the specifics of their thinking (Potebnja, 1993).

According to D. Ovsyaniko-Kulikovsky, the language is the basis of the folk psyche and the leading feature of the nation. The scientist noted that a person according one's parents nationality and place of birth is a representative of a certain nation. However, if this person lives in another country and is brought up by the means of language and culture of another nation, then one becomes the representative of this nation, because a linguistic connection between that person and its native nation has been lost (Ovsianiko-Kulikovsky, 1922).

Taking into account the views of D. Ovsyaniko-Kulikovsky and O. Potebni and without pretending to consider all the consonant thoughts that are quite numerous, we can conclude that the language of communication is an important condition for the development of the national identity of Ukrainians. 
Summing up the considered scientific provisions, we note that the personality's national identity is the result of the awareness of its own affiliation with a certain nation and its emotional evaluation of this membership. One of the conditions for the development of the personality's national identity is the language of her communication.

The aim of our research was to study the language of communication as a condition for the development of the national identity of student youth. The objectives of the research that contributed to this aim were: theoretical analysis of the leading scientific psychological positions of scientists, which concern the essence of the personality's national identity and the main conditions of its development; empirical study of the language of communication of Ukrainian students of higher educational institutions, definition of their type of national identity and determination of whether the language of communication is the main condition for the development of the national identity of the student youth in Ukraine.

\section{Methods and methodology of research}

An empirical study was carried out to achieve the aim and solve the identified tasks. For the empirical study of such a condition for the development of the national identity of student youth, as a language of communication, were applied ethnopsychological questionnaire (adaptation V. Sokolova) and method «Types of Ethnic Identity» (authors - G. Soldatova and S. Ryzhova), which have been modified by us (Spivak, 2015).

In particular, ethnopsychological questionnaire used questions related to the native language and the language of communication. Namely - the question: «Which language (or languages) do you communicate in a family, family circle?», «Which language (or languages) do you communicate with your friends, peers?» The students' answers to these questions were compared with their answers to the question of which language they consider to be their native language.

The use of the method «Types of Ethnic Identity» has helped to establish the types of national identity in respondents - positive or transformed. Analysis and comparison of the results of the methods used allowed achieving the aim of the research. 


\section{Results and discussions}

The study, which was conducted during 2016-2017, was done by 309 students of 1-4 years of study, aged 17-21, from higher educational institutions of Kyiv, Rivne, Berdyansk and Kamyanets-Podilsky. Out of these ones, 77 students of the first year of studying, 76 students of the second year of studying, 79 students of the third year and 77 students of the fourth year of studying. All respondents are Ukrainians according to their nationality.

To illustrate the quantitative data obtained with the ethnopsychological questionnaire and relate to the language of communication between students of 1-4-year of studying with significant others, filed in Figure 1.

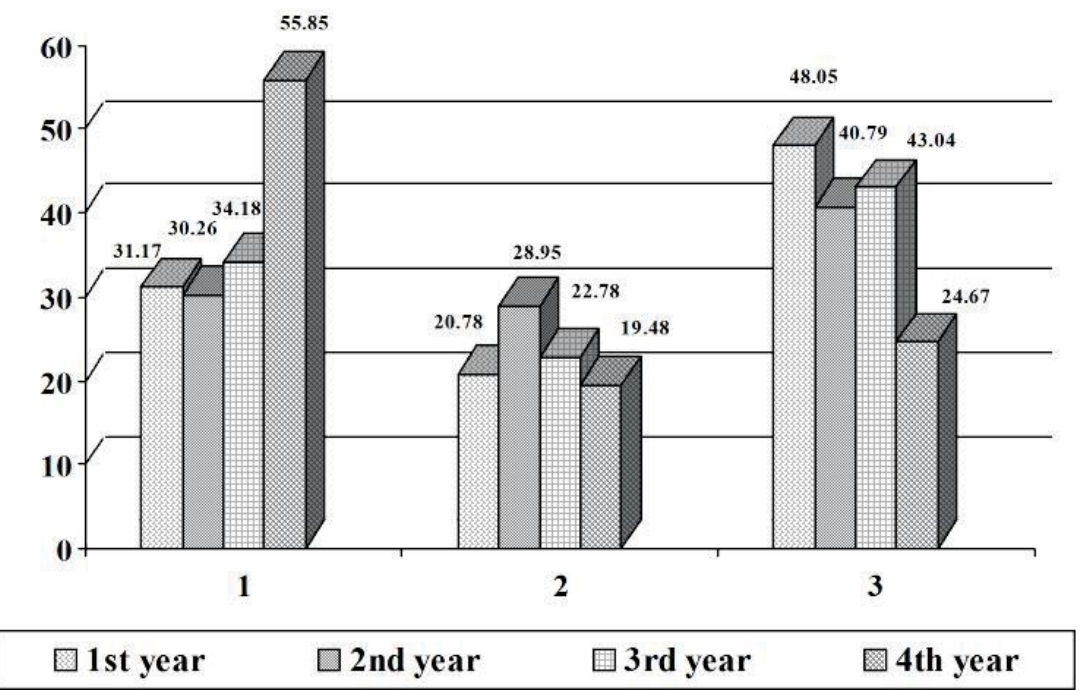

Figure 1. Histogram of quantitative data on the language of communication of the students of 1-4-years of studying with significant others (\%)

Description: 1 - Ukrainian language; 2 - Russian language;

3 - Ukrainian, Russian and English languages.

As can be seen in Figure 1, the number of students who speak Ukrainian with their relatives, friends and peers is significantly increasing from the first to the fourth year of studying while studying at a higher educational establishment. So, if during the first year of studying the 
number of such students is $31.17 \%$, during the second one $-30.26 \%$, during the third one $-34.18 \%$, then during the fourth one $-55.85 \%$. The established dynamics, on the one hand, is interpreted by the fact that they all regard the Ukrainian as their native language. On the other hand, this dynamics is due to the fact that the language of studying students in higher educational institutions is Ukrainian.

The number of respondents who speak Russian with their significant others was lower compared to the data presented above and insignificantly different for each course. In particular, the number of such students during the first year of studying $-20.78 \%$, during the second year of studying $-28.95 \%$, during the third year of studying $-22.78 \%$ and during the fourth one $-19.48 \%$. These respondents believe Russian language is their native language. However, it is worth taking into account that they only communicate in Ukrainian while having their educational classes in higher educational institutions and while talking with their teachers. In general, from the first to the fourth year of studying, we state the decrease in the number of students who speak Russian with their significant others.

The number of researchers, who often speak Ukrainian and rarely Russian and English with their relatives, friends and peers, is quite large during the first three years of studying and much less during the fourth year of studying. In particular, during the first year of studying, the number of such students $-48.05 \%$, during the second one $-40.79 \%$, during the third one $-43.04 \%$ and during the fourth one $-24.67 \%$. As you can see, during the fourth year of studying the number of students who speak Ukrainian, Russian and English languages with other significant is significantly reduced. The recorded dynamics is related to the fact that the language of studying students is Ukrainian, whereas English is compulsory for studying by many students, as well as the fact that they consider Ukrainian, Russian or both languages their native languages.

Consequently, it is empirically established that the number of students who speak Ukrainian with their significant others significantly increases during the period of studying at the higher educational establishment from the first to the fourth years of studying and the number of students who apply to speak several languages with their significant others is reduced - more often Ukrainian, and less often Russian and English. From the first to the fourth year of studying 
recorded a slight decrease in the number of respondents who speak Russian with their significant others.

Using the modified method «Types of Ethnic Identity», the type of respondents' national identity was positive or transformed. We emphasize that the majority of students, during all years of studying, has a positive national identity (norm). In particular, $81.82 \%$ of first-year students, $80.26 \%$ of second-year students, $87.34 \%$ of third-year students and $84.42 \%$ of fourth-year students are positive national identities. Respondents with a positive national identity characterize a high value relation to the representatives of their nation (language, culture, history, territory etc). Their attitude towards the attributes of their nation is combined with a positive attitude towards the attributes of other nations. They are also respectful to other members of their nation and tolerant to representatives of other nations. Many of them are ready to interact with representatives of other nations, despite international differences. Students with a positive national identity are proud of their belonging to the Ukrainian nation and do not conceal their nationality either in their interaction with representatives of other nations or while visiting other countries. They are characterized by the fact that they favour the values of their nation and the way of life of its representatives.

The transformation of national identity was established among a small number of subjects. Transformed types of national identity were found in $18.18 \%$ of first-year students, $19.74 \%$ of second-year students, $12.68 \%$ of third-year students and $15.58 \%$ of fourth-year students. Such deviations, depending on the type, may be manifested in the desire to dominate other nations or, on the contrary, take advantage of them, experiencing lesser respect to their nation and affiliation.

Thus, according to the results of the studies made by G. Soldatova, the transformed types of national identity are presented in their uneven deviations from the norm - positive national identity. The scientist believes that the transformed types of national identity are: national fanaticism, national isolationism and national egoism (hyperidentity, national nihilism (hypoidentity) and national indifference. She found that national fanaticism was manifested: in the readiness of people to all actions for the sake of the interests and well-being of their nation; the provision of social privileges and the exclusive right to use the resources of the nation only to its representatives; recognition of the priority of the national rights over the human rights. The evidence of 
national isolation is: xenophobia; human confidence that one's nation predominates; the struggle to preserve the purity of the national culture; preventing international marriages. Manifestations of national egoism are: tension and irritation of people in interactions with representatives of other nations; frequent reminders of their nation in such interactions; recognition of the right of the nation to solve all problems by means of other nations.

National nihilism is characterized by the following manifestations: the lack of a nation desire to maintain the values of one's nation; a sense of shame and inferiority, the appearance of which is due to their own nationality; difficulties in interacting with the representatives of their nation sometimes combined with negative attitudes towards them. National indifference is manifested in people's indifference to their own nationality; according to their beliefs about the insignificance of their nationality in everyday communication; a neutral attitude towards all other nations and their characteristics, in particular to their own one (Soldatova, 1998).

The next stage of our research determined whether the language of communication could be considered an important condition for the development of a positive national identity of the Ukrainian student youth? To prove that, by means of the correlation coefficient made by Ch. Spirman, a connection between the language of communication and the type of national identity of students - positive, transformed was established. The correlation analysis confirmed the existence of such a connection $\left(\mathrm{r}_{\mathrm{s}}=0.581, \mathrm{p} \leq 0.01\right)$ and allowed us to state that the language of communication is an important condition for the development of the national identity of the student youth of Ukraine. In particular, it was discovered that most students with a positive national identity speak just Ukrainian with their significant others, or speak several languages - more often Ukrainian and rarely Russian and English. Thus, in general, it has been proved that speaking Ukrainian is a basic condition for the development of positive national identity of Ukrainian student youth.

\section{Conclusions}

The conducted research made it possible to draw such conclusions. Personality's national identity is the result of one's awareness and 
emotional assessment of one's own affiliation with a particular nation. An important condition for the development of the personality's national identity is the language of one's language. Student's age is sensational for the development of national identity. The language of communication of Ukrainian students with meaningful other (native, friends, peers) is empirically determined. It is revealed that during the studies at higher educational institutions from the first to the fourth year the number of students who communicate with other significant Ukrainians significantly increases and the number of students who apply to communicate with meaningful other several languages is reduced - more often Ukrainian and, less often, Russian and English. It is empirically determined that most respondents have a positive national identity. It is proved that during this age the individual speaking language is an important condition for the development of one's national identity. It is empirically determined that most respondents speak Ukrainian with their significant others. It is revealed that most students with a positive national identity speak just Ukrainian with their significant others, or they speak several languages - more often Ukrainian and rarely in Russian and English.

The prospects for further research are seen in the study of the influence of other nation features on the development of the Ukrainian student's national identity and the influence of cross cultural features of the language of communication on the student's national identity development.

\section{References}

Altman, C. (2015). Two Measures of Bilingualism in the Memories of Immigrants and Indigenous Minorities: Crossover Memories and Codeswitching. Journal of Psycholinguistic Research, 44, 187-200. doi:10.1007/s10936-014-9288-4

Barrett, M. (1996). English Children's Acquisition of a European Identity. In Changing European Identities: Social-Psychological Analyses of Social Change (pp. 145172). Oxford : Pergamon Press.

Dekeyser, R., Alfi-Shabtay, I., \& Ravid, D. (2010). Cross-linguistic evidence for the nature of age effects in second language acquisition. Applied Psycholinguistics, 31, 413-438. http://dx.doi.org/10.1017/S0142716410000056

Gnatenko, P.I., \& Pavlenko, V.N. (1999). Identichnost: filososlkiy i psikhologicheskiy analiz [Identity: philosophical and psychological analysis]. Kyiv : Naukova Dumka [in Russian].

Joseph, John. E. (2004). Language and identity: national, ethnic, religious. Hampshire : Palgrave MacMillan.

Lozova, O.M. (2009). Psykhosemantyka publicystychnogho tekstu: etnichne i sociokuljturne [Psychosemantics of Journalistic Texts: Ethnic and Socio-cultural Aspects]. Psiholingvistika - Psycholinguistics, 4, 76-81 [in Ukrainian]. 
Oakes, L. (2001). Language and National Identity: Comparing France and Sweden. Amsterdam : John Benjamins.

Ovsianiko-Kulikovskii, D.N. (1922). Psikhologiia natsionalnosti [Psychology of nationality]. Peterburg : Vremia [in Russian].

Piontkovs'ka, D.V. (2017). Psykholohichni osoblyvosti rozvytku natsionalnoyi identychnosti studentskoyi molodi [Psychological Features of Development of Student's National Identity]. Extended abstract of candidate's thesis. Ostroh [in Ukrainian].

Potebnia, A.A. (1993). Mysl $i$ iazyk [Thought and Language]. Kyiv : SINTO [in Russian].

Shevchenko, O.V. (2015). Nacionalna identifikacija u stanovlenni Ja-obrazu osobistosti [National Identification in Becoming of the Person's Self-image]. Extended abstract of candidate's thesis. Kyiv [in Ukrainian].

Smit Entoni, D. (1996). Natsionalna identychnist [National Identity]. Kyiv : Osnovy [in Ukrainian].

Soldatova, G.U. (1998). Psikhologiya mezhetnicheskoi napryazhonnosti [Psychology of Interethnic Tension]. Moscow : Smysl [in Russian].

Spivak, L.M. (2015). Psykhologiya rozvytku natsionalnoi samosvidomosti osobystosti v yunosti [Psychology of development of personality's national self-consciousness in youth]. Kamyanets-Podilsky : Ruta [in Ukrainian].

Suleiman, C., \& O'Connell, D.C. (2008). Gender Differences in the Media Interviews of Bill and Hillary Clinton. Journal of Psycholinguistic Research, 37, 33-48 DOI:10.1007/s10936-007-9055-X

Suleiman, C., \& O'Connell, D.C. (2008). Race and Gender in Current American Politics: A Discourse-Analytic Perspective. Journal of Psycholinguistic Research, 37, 373-389. doi: 10.1007/s10936-008-9087-x

\section{АНОТАЦІЯ}

Статтю присвячено такій важливій умові розвитку національної ідентичності студентів вищих навчальних закладів України, як мова їх спілкування. Презентовано авторське розуміння психологічної сутності феномена "національна ідентичність", що полягає в усвідомленні та оцінюванні особистістю власної національної належності. Національна ідентичність особистості - результат усвідомлення нею своєї належності до певної нації та ії емоційного оцінювання цієї належності. Сенситивним для розвитку національної ідентичності визначено студентський вік. Подано основні психологічні позиції вчених про умови розвитку національної ідентичності, зокрема і мову спілкування. Презентовано положення О.О. Потебні й Д.М. ОвсяникоКуліковського про значення мови спілкування у розвитку національної ідентичності українців. Емпірично встановлено мову спілкування української студентської молоді зі значущими іншими (рідними, друзями, ровесниками). З'ясовано, що протягом навчання у вищому навчальному закладі від першого до четвертого курсу значно збільшується кількість студентів, які спілкуються зі значущими іншими українською мовою і 
зменшується кількість студентів, які застосовують для спілкування зі значущими іншими кілька мов - частіше українську і рідше російську й англійську. Емпірично визначено, що більшість респондентів мають позитивну національну ідентичність. Доведено, що основною умовою розвитку позитивної національної ідентичності українських студентів вітчизняних вищих навчальних закладів виступає їх спілкування зі значущими іншими мовою своєї нації. Зокрема виявлено, що більшість студентів із позитивною національною ідентичністю спілкуються зі значущими іншими або однією, українською мовою, або ж кількома мовами - часто українською $і$ рідко російською та англійською. Перспективними для подальшого вивчення вважаємо питання впливу інших ознак нації на розвиток національної ідентичності української студентської молоді та кроскультурних особливостей впливу мови спілкування на розвиток національної ідентичності студентів вищих навчальних закладів.

Ключові слова: національна самосвідомість, особистість, розвиток, мова спілкування, студентська молодь.

\section{Спивак Любовь, Коваленко Елена. Язык общения как условие развития национальной идентичности студенческой молодежи Украины}

\section{АННОТАЦИЯ}

Статья посвящена такому важному условию развития национальной идентичности украинских студентов высших учебных заведений, как язык их общения. Представлено авторское понимание психологической сущности феномена "национальная идентичность", который заключается в осознании и оценке личностью собственной национальной принадлежности. Национальная идентичность личности - результат ее осознания своей принадлежности $к$ определенной нации $и$ ее эмоционального оценивания этой принадлежности. Сенситивным для развития национальной идентичности определен студенческий возраст. Представлены основные психологические позиции ученых об условиях развития национальной идентичности, в том числе и языке общения. Представлены положения А.А. Потебни и Д.Н. ОвсяникоКуликовского о значении языка общения в развитии национальной идентичности украинцев. Эмпирически установлено язык общения украинской студенческой молодежи со значимыми другими (родными, друзьями, сверстниками). Установлено, что на протяжении обучения в высшем учебном заведении от первого до четвертого курса значительно увеличивается количество студентов, которые общаются со значимыми другими на украинском языке и уменьшается количество студентов, применяющих для общения со значимыми другими несколько 
языков - чаще украинский и реже русский и английский. Эмпирически установлено, что большинство респондентов имеют положительную национальную идентичность. Доказано, что основным условием развития положительной национальной идентичности украинских студентов отечественных высиих учебных заведений является их общение со значимыми другими на языке своей нации. В частности выявлено, что большинство студентов с положительной национальной идентичностью общаются со значимыми другими или на одном, украинском языке, или же несколькими языками - чаще на украинском и редко на русском и английском. Перспективными для дальнейшего изучения считаем вопросы влияния других признаков нации на развитие национальной идентичности украинской студенческой молодежи и кросскультурных особенностей влияния языка общения на развитие национальной идентичности студентов высших учебных заведений.

Ключевые слова: национальное самосознание, личность, развитие, язык общения, студенческая молодежь. 